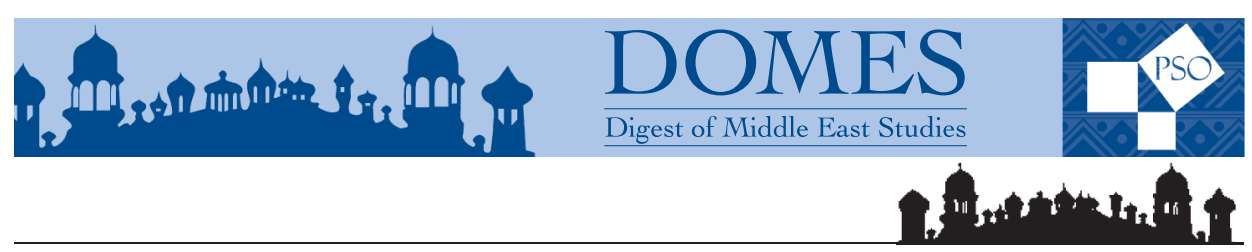

\title{
Intergroup Dialogue as a Just Dialogue: Challenging and Preventing Normalization in Campus Dialogues
}

\author{
Manal Yazbak-Abu Ahmad, PhD \\ Sakhnin Teachers College \\ Sakhnin, Israel
}
Adrienne B. Dessel, PhD, LMSW
University of Michigan
Ann Arbor, Michigan

Alice Mishkin, LLMSW

University of Michigan

Ann Arbor, Michigan

Noor Ali, MSW

Northwestern University

Evanston, Illinois

Hind Omar

University of Michigan

Ann Arbor, Michigan

\begin{abstract}
The tensions from the Israeli occupation of Palestine reach around the globe and heated debates over the struggles of these two peoples are evident on U.S. college campuses. The power imbalance represented in the relationship between Palestinians and Israelis is replicated on college campuses. BDS (Boycott, Divestment, and Sanctions) is a response to this inequality, is a movement to end the occupation, and has raised the issue of normalization. Teaching about this conflict presents particular challenges for faculty who negotiate this highly contested issue in classrooms or campus communities, and intergroup dialogue is an important pedagogy that can be used. It is critical to address normalization in intergroup dialogue. We discuss examples and themes of normalization in intergroup dialogue, and present pedagogical and other strategies to prevent and address normalization in intergroup dialogue and in other similar intergroup contact approaches with Arab or Palestinian and Jewish or Israeli participants.
\end{abstract}




\section{Introduction}

Tn 1948, Israel occupied Palestine, depopulating about 500 villages and evicting about 2 million Palestinians who fled to the West Bank and neighboring Arab Counties. Twenty percent of Palestinians who remained are referred to as the indigenous minority group. They live in a state that was forced on them and does not represent them. This situation has resulted in setting them apart from all the groups surrounding them (Israelis, Palestinians in Gaza, and the West Bank) (Ghanem \& Mustafa, 2011). These Palestinians, who stayed in Israel, were given an Israeli identity but were not granted equal rights. The Palestinians in Israel, who have also been called "The Israeli Arabs," "The 48 Arabs," or the "Arabs within the Green Line," are struggling for social justice in a country that defines itself as a Jewish state and ignores the one-fifth of its population who are Palestinian citizens (Dakwar, 2006).

In 1967, Israel occupied the West Bank, Gaza, and the Golan Heights. This war influenced the political, economic, and social transformation of Palestinians in Israel, and it coincided with the cessation of the military rule that isolated them from their Palestinian and Arab surroundings. Consequently, the increased contact between Palestinians from inside and outside of Israel contributed to a feeling of a shared destiny and the feeling that Arab Palestinians in Israel are an inseparable part of the Palestinian case (Dakwar, 2006; Ghanem \& Mustafa, 2011). Although this indigenous minority group has been oppressed over the last 67 years, it has managed to enter the political scene through its struggle for social justice (Hamdan \& Awad, 2010). Fortunately, in the recent Israeli elections, which took place on March 2015, the different Palestinian Israeli parties finally managed to unite to form a joint United Arab party in the Israeli Knesset (Parliament) so that now they are considered a force that cannot be overlooked by the Israeli government (Wagner, Frantzman, \& Kelly, 2015).

On the other hand, the Palestinians in the West Bank and Gaza faced another reality. They were considered as "jurisdictional entities separate from the State of Israel" (Karayanni, 2009). They lived under the military rule until the Oslo Treaty, which took place on May 20, 1993, and were economically dependent on Israel. After the Oslo Treaty, the Palestinians started to gradually take over some cities in the West Bank until the second Intifada in 2000 when Israel gained control over the West Bank again. Israel has always tried to minimize the urban planning of Palestinian cities while continuing to build more and more settlements in the West Bank. Needless to say, one clear example of the daily occupation that the Palestinians endure is the Israeli requirements for building permits for all construction outside the boundaries of their towns (Thawaba, 2009).

The tensions from this occupation reach around the globe, and heated debates over the struggles of these two peoples are evident on U.S. college campuses. (Gross \& Williams, 2009; Lopez, 2003; Schworm, 2009; Shibley, 2014). The power imbalance represented in the relationship between Palestinians and Israelis is replicated on college campuses (Dessel \& Ali, 2012b). BDS is a response to this inequality and a movement 
to end the occupation, and has raised the issue of normalization (Dessel \& Ali, 2012b). The BDS movement started in September 2005. The Palestinian Public Forces, unions, and political alliances, both in the 1967 and 1948 territories, in addition to all the political and ideological bodies in the diaspora have joined in the call for BDS. The movement had two alternatives: the International Law or the "Jungle Law," and since the latter would not serve the oppressed side, the former might benefit the Palestinian case, especially as it comprised their ideological vision, volition, strategic planning, accountability, democratic development, and wider alliances (Barghoti, 2014).

Teaching about this conflict presents particular challenges for faculty and staff who negotiate this highly contested issue in classrooms or campus communities (Buie \& Wright, 2010; Gravois, 2004). One way to teach about normalization and these multiple intergroup conflicts is using Intergroup Dialogue (IGD). This article examines an Arab-Jewish intergroup dialogue course and is the result of research on normalization that was prompted by feedback from students who were in the course. The article will first define normalization, and then provide examples of and critique this concept and why it is relevant to this intergroup dialogue course and important to address in the context of intergroup work. We will next describe intergroup dialogue pedagogy, and then discuss the Arab-Jewish intergroup dialogue course that we have taught. We will provide quotes from the Arab-Jewish intergroup dialogue course that offer examples of what normalization can look like in intergroup dialogue, outlining four themes found in our coding of student final papers and interviews. Finally, and most importantly, we will discuss pedagogical and other strategies to prevent and address normalization in intergroup dialogue and in other similar intergroup contact approaches with Arab or Palestinian and Jewish or Israeli participants.

\section{Defining Normalization}

The majority of the Palestinian population lives in the diaspora. According to the Palestinian Central Bureau of Statistics (2009), 6.8 million Palestinians live in the diaspora, compared to 3.99 million living in the Palestinian Territories (i.e., 2.5 million in the West Bank and East Jerusalem, and 1.5 million in Gaza). There are 1.25 million (11.5\%) Palestinians who live in Israel, 3.24 million (29.8\%) in Jordan, 1.78 million (16.3\%) in the other Arab countries, and about 618 thousand (5.7\%) living in foreign countries (PACBI). Ben-David (2012) found a shift from organizations of Palestinian communities abroad to a transnational solidarity network on Palestinian rights and the Boycott movement. Diaspora Palestinian's level of political engagement is wide and Palestinians living in Israel may have a different perspective on normalization and even their willingness to use the word (Walid, 2005).

PACBI (Palestinian Campaign for the Academic and Cultural Boycott of Israel) is a political activist organization that has developed the following definition of normalization:

Normalization is the participation in any project, initiative or activity, in Palestine or internationally, that aims (implicitly or explicitly) to bring together 
people in solidarity with Palestinians or Palestinians (or Arabs) with proIsraeli (people or institutions) without placing as its goal as resistance to and exposure of the Israeli occupation and all forms of discrimination and oppression against the Palestinian people (PACBI, 2015).

However, in this definition, there is no reference to the delicate and different situation for the Palestinians living in Israel (Azaizeh, 2015) who are assimilating and integrating into Israeli society (Koren, 2002). For some Palestinians, normalization (tatbi'a) may also be defined as "the process of building open and reciprocal relations with Israel in all fields, including the political economic, social, cultural, educational, legal, and security fields'. Some say the word tatbi'a must not be used because it refers to conducting normal relations with Israel, which is currently impossible" (Walid, 2005: 100). Diaspora Palestinians may also have a different definition of normalization, for example, accepting the status quo without taking action (Abu Sarah, 2011). When considering these different definitions, the relative proximity to the occupation, and the different degrees to which various Palestinian communities are affected, should be taken into account.

\section{Criticism of Antinormalization}

Recently, Jewish Scholars for Israel and Palestine and the Alliance for Academic Freedom (AAF) released a joint statement (2015) criticizing antinormalization practice (The Third Narrative, 2015). Their concerns focus on the perspective that antinormalization work further separates Palestinians and Israelis, thus limiting Palestinians from sharing their perspectives and connecting with Israelis who are activists for Palestinian causes. They also fear this approach creates difficulties for Palestinians within their own community when they want to work with Israelis. Finally, they worry that the antinormalization movement restricts academic freedom of expression and disrupts learning about the other group. While they do acknowledge the importance of attending to power imbalances, they target efforts such as the BDS movement as particular roadblocks in coexistence efforts. They believe this movement is problematic in that it challenges the existence of the Jewish state of Israel (McMahon, 2014; The Third Narrative, 2015).

Similarly, Aziz Abu Sarah, a Palestinian from Jerusalem living in the diaspora, echoes the same concerns in his article, "What is normal about Normalization?" (2011), where he claims that refusing to engage or cooperate with pro-Palestinian Israelis leads to more segregation between political groups. He does emphasize the importance of taking action, in the form of cooperation between Palestinians and Israelis whose goal is to end the occupation and to work for human rights for the sake of common humanity.

In addition, Ray Hanania (2011), who is another Palestinian from Jerusalem, believes that the people who are against normalization are afraid that if the two people start treating each other with respect, there will be no more conflict and thus they will never reach 
a resolution. He claims that the fanatics from both sides do not want to compromise, and each is seeking the demolition of the other. He also relates to the Palestinians who are harassed by the fanatics in their own community once they decide to cooperate with Israelis for peace. On the other hand, Hanania states that one should acknowledge that there are Israelis who are working for genuine peace. Finally, he sees normalization as the first step toward ending this conflict through compromise and creating a Palestinian State while insuring Israel's continued existence. This, for him, does not mean that he will stop criticizing Israeli policies and actions.

\section{Resistance to Normalization}

In order to address possible occurrences of normalization within Arab-Jewish dialogues, it is important to set up a framework of resistance. At its core, a framework of resistance acknowledges ending the occupation and the right of return for Palestinian refugees (PACBI, 2015). This includes supporting human rights for Palestinians and challenging their oppression by Israel. It is also important to move from a model of coexistence, which may not acknowledge the power differentials between Palestinians and Israelis or Jews and may seek to emphasize commonalities (Biton, 2002; Maoz, 2011; Solomon, 2004) to a model of co-resistance (PACBI, 2015). This model requires participants to move beyond friendships and into activism and allyhood based on solidarity with the Palestinian people. There are multiple models of coresistance including: direct action and civil disobedience in the region and in the United States; participation in international campaigns that seek to put pressure on the Israeli government to end the occupation, such as the Boycott, Divestment, and Sanctions movement; and, for Jewish students in particular, co-resistance can take the form of educational work within their own communities (Bekerman, 2007; Rahman, 2012). While some coexistence programs do incorporate attention to power dynamics and asymmetry (Abu-Nimer, 2004; Maoz, 2001; Rouhana \& Korper, 1996), many struggle with balancing social power in these dialogue settings (AbuNimer, 2004; Ben Hagai, Hammack, Pilecki, \& Aresta, 2013; Maoz, 2000; Suleiman, 2004; Yazbak-Abu Ahmad \& Yahav, 2015). In his article, "Co-existence vs. Co-resistance: A Case against Normalization" (January 3, 2013), Rahman claims that projects that address normalization portray a false reality in which the oppressor convinces himself of a just resolution of the conflict. He states that the Israelis falsely think they are working for peace while in reality they are only unintentionally fossilizing the status quo. He continues to say that if the Israelis are working to end the occupation, cooperation between the two sides is justified.

\section{Intergroup Dialogue}

Intergroup dialogue is a pedagogical method that can be used to teach about the Israeli-Palestinian conflict and address tensions between Arab and Jewish students on college campuses (Dessel \& Ali, 2012a, 2012b; Dessel, Ali, \& Mishkin, 2014). 
While intergroup dialogues involving Arab and Jewish students have been used in Israel (Abu-Nimer, 1999; Halabi, 2000; Mollov \& Lavie, 2001), very few U.S. campuses utilize this method. Khuri (2004a, 2004b) taught a seven-week campus dialogue course that was focused on supporting students in positive expression of emotions and productive engagement with the conflict in order to promote a deeper understanding of the complexity of the issues. One person identified as Palestinian, and three others identified as Jewish, whereas the rest of the participants were of other different identities. Participants tended to focus on either pro-Palestinian or pro-Israeli views. This created an interesting dynamic within the group that became an obstacle for facilitators who tried to balance airtime and topics of interest. Students reported clarifying their own beliefs, increasing their understanding and ability to interact with others who held different views, and recognizing multiple perspectives. Khuri (2004b) emphasized the importance of attending to emotion in intergroup dialogues on this topic.

The Arab-Jewish intergroup dialogue course examined in this study was designed by a research team of Arab and Jewish students in conjunction with program faculty and staff. These dialogue courses engage students from two different identity groups across social conflict, and are facilitated by peers who represent the different identities. The course focuses on the Arab-Israeli conflict, and this name was chosen because Arab and Jewish students are engaged around this issue on campus. The course is based on the contact theory (Allport, 1954; Pettigrew \& Tropp, 2006), which states that there are four conditions that promote positive contact. The first one involves support and encouragement of intergroup contact from authority figures, the second one requires equal status of the two groups, the third is cooperation between members of the two groups, and the fourth is having enjoyable and intimate encounters that foster meaningful interaction among the participants. A large meta-analytic study (2006) found that these contact effects reduce intergroup prejudice. IGD uses a social justice pedagogy that engages roughly equal numbers of students from two different social identity groups who are in conflict with one another in a semester course that is highly structured and facilitated by trained student peers representing the two identities (Abu-Nimer, 1999; Dessel \& Ali, 2012b; Halabi, 2000; Khuri, 2004a; Mollov \& Lavie, 2001). This two credit undergraduate course (which is now three credits) follows a four stage group model that includes creating a shared meaning of dialogue, exploring social identity and conflict, examining contemporary social justice topics and conflicts, and building alliances and next steps. Students are assigned relevant readings each week, and engage in experiential activities and exercises designed to promote critical selfreflection around social inequalities and perspective taking of others. Intergroup dialogue follows a process-content model that promotes both cognitive and affective learning (Zúñiga, Nagda, Chesler, \& Cytron-Walker, 2007). Assignments include weekly journals that the students submit and an intergroup collaboration project at the end of the semester. 
The Arab-Jewish intergroup dialogues examined in this study have an intentional focus on power dynamics and social inequality (Zúñiga et al., 2007). The educational goals of the dialogue are increased awareness of social identities and related inequalities, development of communication skills and relationships across conflict, and strengthening capacity for social justice action. In stage two, the students examine the different definitions and examples of normalization, and explore how their own group identity relates to the concept of normalization. For example, we have a handout on normalization that discusses the definition, how normalization relates to dialogue, whether normalization is a problem, and examples of normalization in previous dialogues.

Previous research on the course has examined outcomes over four semesters. Students' pre papers and post papers and post interviews are audiotaped and transcribed, and a research team of Arab and Jewish students coded the transcribed interviews. Results indicated that all students developed skills of critical self-reflection about their views on the conflict, communication and active listening skills, and perspective taking and empathy toward the other group, which led to positive changes in perceptions of the other group. Students reported "humanizing" the other, friendships and alliances were built, and students reported new awareness of power and privilege dynamics, and intended and actual actions taken to combat prejudice, oppression, and discrimination against one another's group on campus. Additionally, Jewish students discussed resistance to acknowledging their privileged status on campus as compared to Palestinian or other Arab students, and both groups retained their strong connection to their own identity with regard to the land in Israel and Palestine (Dessel \& Ali, 2012b).

\section{Normalization, Dialogue Programs, and Student Activism}

Discussing normalization involves many layers for Palestinians who live in Israel, West Bank, Gaza, and in the diaspora. One example of normalization is coercive everyday relations for Palestinian citizens of Israel and in the West Bank that are necessary for survival. Palestinians have to pay taxes to the Israeli government, and Israeli companies employ them (Halper, 2006). Language is another example of normalization. While for the Palestinians in Israel, Hebrew is a requirement in the school curricula, the Palestinians in West Bank and Gaza need it in the work force.

A third example includes engagement in international forums representing Israel (i.e., cooperative ventures). This could be international conferences, or participation in cultural and educational activities such as dance or arts performances. Specifically for Palestinians in Israel, the BDS movement has directly affected them recently as well since a lot of international Arab cultural performances that are scheduled to take place in Israel are being cancelled (Anonymous, 2013). In her article, "The Road to Tel Aviv doesn't pass from Acca," Asmaa Azaizeh (2015), who is a Palestinian in Israel, discusses the recent BDS movement that West Bank Palestinians 
are pushing, which opposes the participation by any Arab or West Bank Palestinians in any cultural performance within the Green Line. This article was written as a response to the pressure that the BDS movement forced on "Harqet Kart," a Jordanian Musical Band, which was scheduled to perform in the mixed city of Acca in the north of Israel. Azaizeh addresses the delicate situation of the Palestinians in Israel who were automatically normalized. The Palestinian existence within the Green line demands, in her opinion, a greater effort from the BDS movement to fairly address their historical situation and their identity. Like Ghanem and Mustafa (2011), she refers to the deliberate absenteeism and alienation of the Palestinians in Israel from the political debates. She also claims that performances such as the one in Acca will not, as BDS supporters fear, lead the way to Tel Aviv performances. Finally, Azaizeh criticizes the part of the BDS definition of cultural performances that acknowledges only the West Bank as Occupied Palestine.

A fourth example is expecting Palestinian solidarity groups to meet or work with pro-Israeli groups on U.S. college campuses when there are asymmetrical power dynamics and relationships with college administration as well as unequal access to resources (Keilani \& Heitner, 2013).

Normalizing dialogue programs on campuses may take the form of courses offered by the university or trips of Arab and/or Palestinian students and Jewish students to Palestine. Many of these programs, such as the Olive Tree Initiative (OTI) in the University of California school system, refuse to take a stance on the occupation of Palestine and claim to be "apolitical" (Kurwa, 2013a). There is debate about this perspective as others have criticized the OTI for hosting a Hamas leader (Anonymous, 2011). Normalizing programs often frame the relations between Israelis and Palestinians as symmetrical and present the occupation as a war or "conflict" between Palestinians and Israelis for which the Palestinians are equally responsible.

In addition programs like the Slim Peace weight-loss dialogue program introduced to George Mason University in 2014 project an image that the occupation is a "disagreement between parties who just need to learn to see eye to eye" (Radi, 2014, para. 7). These programs also identify their goal as peace, coexistence, "empathy" or understanding without mention of justice for Palestinians and an end to the occupation, or co-resistance (Radi, 2014).

In 2011, the Boycott, Divestment and Sanctions movement called on supporters of BDS to refrain from participating in normalizing programs and events, including programs that seek to "encourage dialogue or 'reconciliation between the two sides' without addressing the requirements of justice” for Palestinians (Pacbi.org). Many student activists have responded to this call by amplifying their efforts to resist normalization on their campuses. Student activists frequently refer to PACBI's statement in their antinormalization activism and cite it when raising critical questions about the relationship between dialogue and dialogue programs, normalization and the movement for a just end to the occupation of Palestine (Kurwa, 2013a). 
Palestine solidarity groups push back against normalization on their campuses in many ways. Student activists, such as Tareq Radi, a former student at George Mason University and founder of SAIA (Students against Israeli Apartheid) publish news and magazine articles to raise awareness about normalizing programs on their campuses. Radi encourages students to avoid the Slim Peace dialogue program, a weight loss "nutritional dialogue program" targeted toward Muslim and Jewish college-aged women (Radi, 2014). Radi also created several infographics outlining key aspects of the PACBI definition of normalization, buzzwords commonly associated with normalizing rhetoric, and warning signs an event or program might be normalizing (Radi, 2015). As a student in the University of California school system, Rahim Kurwa described students in solidarity with Palestine who refrained from joining the Olive Tree Initiative (Kurwa, 2013a, 2014). While a member of Columbia University's Students for Justice in Palestine, Tanya Keilani coillustrated and authored a comic titled "Nothing 'Normal' About It: Normalization, Dialogue and Palestine on Campus" that depicts how students in Palestine solidarity groups are often pressured to "dialogue" and normalize with pro-Israeli student groups and how these normalizing demands compromise students' activism. In addition to producing knowledge via news and magazine articles and creating other resources on normalization, students also conduct workshops at gatherings like the National Students for Justice in Palestine conference in order to share strategies on how to resist and prevent normalization (Keilani \& Heitner, 2015; National Students for Justice in Palestine, 2014; Radi, 2014).

\section{Importance of Normalization in the Context of Intergroup Dialogue}

It is important to address the issue of normalization in Arab-Jewish intergroup dialogue courses, and other dialogue topics as well, for a number of reasons. We will discuss these reasons in the context of the Arab-Jewish dialogue and the PalestineIsrael conflict, while recognizing that other dialogue topics also need to attend to this issue of challenging the status quo in order to achieve the goals of social justice (Zúñiga et al., 2007). There is a debate about the role dialogue plays in normalization. In what ways does dialogue normalize the experiences of Arab and Palestinian experiences? How does this happen? Can it be avoided? What are ways structured Intergroup Dialogue can aim to challenge normalization that occurs in a dialogue space? These questions are what we aim to explore here.

The first reason why it is important to address normalization is that not attending to power differentials in intergroup dialogues can contribute to justifying the status quo or supporting dominant narratives. This can look like complacency among participants in their perspective that the issue of power and equality is just too large or complex to tackle, or that the situation is "just the way things are" (Hahn Tapper, 2013; Maoz, 2011). Abu Sarah (2011) has critiqued the use of intergroup encounters as a potential means of maintaining social control and status quo rather than of 
achieving political and social change. Thus, it is critical not to overlook asymmetrical power dynamics in intergroup dialogue (Rouhana \& Korper, 1996).

The second reason is that tensions exist around the connection between dialogue and political activism. While some research has shown that participants in dialogues do engage in social action as a result of participation (Dessel \& Ali, 2012b; LopezHumphreys \& Dawson, 2014), other research has challenged this finding by noting the structural inequality between participants (Abu-Nimer 1995; Sharoni, 1995), or the difficulty participants have in effecting change once they move out beyond the dialogue into the external society (Hubbard, 1997). Maoz (2011) has identified the Narrative/Storytelling models that intergroup dialogue incorporates as challenging the imbalance of power. Bekerman (2007) outlines a number of important approaches to mobilizing intergroup encounter participants for collective social change that are valuable for Palestinian Arab participants. These include organizing and participating around political action goals and advocating for redistribution of resources among Israelis and Palestinians (Bekerman, 2007).

Third, it is important to note that Arabs and Jews may come into the dialogue with different expectations and experiences that are related to their views about and interest in addressing power differentials, and this should be taken into consideration (Dessel \& Ali, 2012b; Rouhana \& Korper, 1996). In some dialogues and other intergroup encounters, Arab participants hold an instrumental approach that aims for intergroup political action, while Jewish participants prefer an expressive approach that addresses interpersonal and psychological interests and seeks to examine commonalities between the two different groups (Abu-Nimer, 1999; Maoz, 2011, Saguy, Dovidio, \& Pratto, 2008).

Finally, intergroup dialogue facilitators of this topic should be aware of the barriers for Jewish students that exist in preventing them from recognizing the power differentials and interfere with their openness to learning about Palestinian narratives (Dessel et al., 2014). These barriers include not knowing Palestinian people and not having been to Gaza or the West Bank to learn about their living conditions, as well as student political views about Israel and their family beliefs about Israel. The media also plays an important role in limiting students' openness to learning multiple perspectives that include Palestinian narratives. It is important for facilitators to recognize all of these influences on student attitudes, and to be sensitive to engaging students around critical reflection of their own experiences and how their views have come to be shaped, as well as what information may be misrepresented or missing in their perspectives and knowledge base about the Israeli/Palestinian conflict.

\section{Normalization and an Arab Jewish Intergroup Dialogue Course}

In this study, we sought to answer the qualitative question of whether normalization occurred in these Arab-Jewish intergroup dialogue courses, and if so, what did it look like? Teaching about normalization was not intentionally incorporated into the 
curriculum during these semesters, and so we wanted to determine if students were making normalization statements, or if they were discussing it directly. This is not an analysis of whether the dialogues created normalization or challenged normalization, as we did not conduct a pre/post analysis examining these questions. This article examines the type of statements that are often considered normalizing in an effort to begin to understand what this phenomenon looks like in intergroup encounters. We then make recommendations for how to prevent and address normalization in such situations.

This data is drawn from two Arab-Jewish intergroup dialogue courses (2012 and 2013) offered by the Program on Intergroup Relations at the University of Michigan, which is described elsewhere and has been shown to promote communication skills, critical reflection on power and privilege, perspective taking and empathy, the development of relationships, and actions for social change (Dessel \& Ali, 2012a, 2012b). The study received IRB (Institutional Review Board) approval from the institution, and consent was obtained for student participation. Student pre papers and post papers, as well as qualitative interviews, were used. Interviews were conducted by trained Arab and Jewish student researchers using an interview protocol developed by student researchers in conjunction with the research team. The interviews were audio recorded and then transcribed.

There were 26 prepapers and 26 post papers (14 Arab, 12 Jewish), and 26 interviews (14 Arab, 12 Jewish). Regarding gender, there were seven Arab females, seven Arab males, six Jewish females, and six Jewish males. The Arab students reported their religion as 12 Muslims, 1 Christian, 1 Agnostic, and the Jewish students all reported their religion as Jewish.

Papers and interviews were coded by an Arab American Palestinian and American Jewish student and then reviewed by the research team. The research team determined the definition of normalization and then the coders used a grounded theory approach (Charmaz, 2011) to examine the data for occurrences of normalization, and further developed subcodes that emerged from the data. Four subcodes emerged, which included three types of normalizing statements, and then direct references to normalization. These codes of normalizing statements or references to normalization were represented in18/26 prepapers (7 Arab, 11 Jewish), 23/26 post papers (12 Arab, 11 Jewish), and 18/26 interviews (9 Arab, 9 Jewish). All student identities were self-reported.

Overall, it should be noted that more Arab than Jewish students referenced normalization in the dialogue itself. This is most likely due to the Arab students' knowledge of this concept, and it being less familiar to Jewish students. Jewish students may have been less exposed to the idea of normalization, or they may have been reluctant to explore this concept that directly addresses power imbalances. We also want to point out here that statements can be both true and normalizing at the same time. Just because a statement is true, it does not mean that it does not normalize relationships and the status quo and promote dominant narratives (Routenberg \& Sclafani, 2010) or supersede other truths. 


\section{Ignoring Power Dynamics}

The first subtheme refers to ignoring power dynamics. This means normalizing statements that erase, distort, or ignore the prevailing power dynamics between Israelis and Palestinians and ignore Israel's role as an occupier and Palestine's status as occupied. Statements like these may represent the relationship between Israelis and Palestinians as one characterized by parity, that is, that both groups are equal. An example of this is the following quote from a Jewish American woman's post interview:

If you look at a person in Palestine, one of the refugees, you think they are being oppressed because they don't have the same rights. But if you look at Israel as a whole, it has all these Arab nations around it and you feel it may be oppressed because it's the only Jewish area. It depends on the perspective you're looking it and the person you're talking to.

In this quote, the student ignores power dynamics in two ways. The student first broadens out the conflict beyond Israel and Palestinians into a larger conflict between the Arab world and Israel. Additionally, the student suggests that because there are more Arab countries than Jewish countries, Arab countries must have more power. While this quote can be considered normalizing, the student's interview also showed tremendous shifts in understanding the conflict from an Arab point of view. The following quote from a Lebanese American Muslim female student's prepaper also represents this theme:

Such wars and conflict have claimed innocent lives on both ends and there seems to be a negligence of this from the perspective of both Israeli and Arab military movements who at times both appear to be on the offense.

This quote is an example of how a statement can be both true and normalizing. While it is true that both Israelis and Arabs have been killed as a result of the conflict, the framing of the statement creates a false equivalency in military power. The student suggests that the Israeli Defense Forces (IDF) and Palestinian militant groups hold equal power, ignoring that the IDF's funding, military supplies and strength far outweigh any Palestinian group's resources (If Americans Knew, 2015).

\section{Justifying the Status Quo}

The second subtheme is justifying the status quo. This refers to the normalizing statements that justify or give an appearance of normalcy to the current status quo of the occupation of Palestine, its foundational beliefs, and its continuation. This is exemplified in the following quote by a Jewish woman's post interview: "[D]espite what happened there's a lot of great things happening in Israel, a lot of great things that Israel does. And in order to do those things they have to protect themselves." Here, a Palestinian American Muslim male student explains in his post interview his perception of the status quo through his experience in the dialogue: "We're just trying 
to find out why the other person feels the way they do about it. And then trying to get them to understand why we feel a certain way about it, and leaving it at there."

This quote highlights normalization because it shows maintenance of the status quo. While students learn about why the other group feels a certain way, this student's perception was that there were no efforts to change minds or challenge socialized understandings.

\section{Interpersonal Misunderstanding}

The third subtheme is interpersonal misunderstanding. This refers to the normalizing statements that reduce or frame the Israeli occupation of Palestine to interpersonal misunderstandings, or lack of trust between Arab and Jewish people or between Israelis and Palestinians, or normalizing statements that frame "solutions" to the occupation as "greater trust" or "understanding" between Arab and Jewish people. This also applies to contexts in which the occupation before 1967 and colonization after 1967 of Palestine is framed as a religious interfaith conflict between Muslim, Christian, and Jewish people. This quote by a Sephardi Jewish man in his post paper exemplifies this theme: "By forming greater understandings of each other's lives and ethnicities, it will be easier to reach peace and acceptance throughout the country, and eventually, the world."

This student talked about his interest in forming alliances, "based on support, trust, association, and the willingness to help," and the importance of developing better relationships. These are necessary goals in this conflict, and alliances cannot be underestimated. However, it is important in intergroup dialogue to not just be content to form these relationships, but to move beyond the important friendships that develop to engage in actions that address structural inequalities and power differentials (Dessel \& Ali, 2012b).

A Palestinian American Muslim woman also struggled with her own interpretation of the conflict in her post paper by stating that:

The conflict is a simple, yet not so simple, misunderstanding that has been dragged on through generations. It has become a matter of every Arab should hate every Jew and vice versa. When in reality, the conflict is not Arab versus Jew, it is Arab versus Zionist, and many people fail to recognize that.

While this student's comments are not entirely normalizing, she is recognizing that some people do see this conflict as an ethnically based dispute, rather than a geopolitical conflict.

\section{Referencing Normalization in the Dialogue}

The last subtheme is acknowledging or referencing normalization in the dialogue. As mentioned, this was found primarily throughout Arab student papers and interviews. This quote by a Palestinian Muslim woman in her post interview gives an example of this: 
Well I just think it's hard to dialogue without normalizing. This actually happened a lot in the course where. . okay maybe other dialogues it's where there's a clear privilege, a clear target group, but with Arab/Jewish, a lot of the times with dialogues that I've seen before tend to make it seem like we're two people with differences that can't seem to get along and then we talk about it and everything will be okay...

She added later on that she believes that the Jewish students did a lot of normalizing in the dialogue, that the dialogue focused too much on interpersonal differences, and that both groups did learn about different experiences and set aside their differences by having continuous discussions. A Palestinian American Muslim male student explained his concern in his post interview about normalization this way:

I think dialoguing with the other side is very much like leading into normalizing which is really problematic and we had a conversation about it, was a weird conversation where people didn't really know what is meant by normalizing and just not understanding how it was like talked about.

He later mentions that dialogue is the most productive method of communication. Hearing the other people's personal story was a positive experience for him, in that these stories gave him more confidence in his beliefs. This view enforces the importance of the contact theory (Allport, 1954) and the power of personal stories (Maoz, 2011).

\section{Strategies to Prevent and Address Normalization}

There are a number of recommendations we offer here as strategies to address and prevent normalization in intergroup dialogue and in other intergroup encounters between Arab and Jewish students on college campuses. These approaches fall into categories of curriculum, facilitation, and population of the students in the dialogue. Some of these recommendations are methods that we are currently using in our intergroup dialogue course, and others are ones that can be considered as well.

\section{Curriculum}

There are a number of pedagogical activities and experiential exercises specifically designed to address some of the challenges of this dialogue topic with regard to normalization and recognizing and addressing power inequality. The first is a power analysis, or power mapping, activity. This is a list of Jewish privileges and Jewish oppressions in the United States, and Arab privileges and oppressions in the United States. These can be broadly in a U.S. context, and also more specific to the campus setting. This exercise can also be extended to the Israel and Palestine context, though we have found it is important to be clear as to whether the analysis focuses on overseas or on the students' U.S. campus. The lists can be offered and also 
generated by students, and then broken down in terms of different types of power: Individual, Institutional, and Structural (Adams, Bell, \& Griffin, 2007). Different sources of power and ways of exercising and sharing power are analyzed in order to better help students understand the nature of power, how and why it is tied to social identity, and what they might work towards in terms of equalizing power inequalities (Just Associates, 2006).

Some examples of Jewish privilege can be white skin privilege, economic resources and social class privilege, access to land in Israel (Birthright trips), political connections on campus, and Jewish representation in faculty and administration or support for Israel in these sectors of campus life. Jewish oppression may be family holocaust history and trauma, anti-Semitism, and racial oppression of Jews of color and invalidation of Jewish identity. Examples of Arab privilege are light-skinned racial privilege, Arab Christians who benefit from the dominant U.S. Christian privilege, and economic resources and social class privilege. Oppressions of Arabs can be seen in lack of freedom of speech, prejudice and discrimination, and racial and ethnic profiling related to the Patriot Act, military occupation, loss of homes, and death of family members in Palestine, no right of return for Palestinians, and Islamophobia for Muslim students. Many of these experiences of oppression are particularly salient for Arab students, as compared to Jewish students, as Arab students are often first generation, whereas Jewish students may be third or fourth generation in the United States.

Another pedagogical method is the use of caucus groups. These are intraidentity groups where the Jewish and Arab students meet separately to explore various questions that pertain to their own experiences and issues related to the I/P conflict, as well as similarities and differences in their experiences across social group identities. These caucuses can provide safer spaces for deeper discussions, and also help students understand the complexities within their own Arab and Jewish identities (e.g., the intersections with gender). It is also important to recognize that some students may identify as both, for example Mizrahi Jews, and to acknowledge this intersectionality and allow students to choose which caucus to attend. Either the Arab or Jewish student facilitator facilitates each caucus group.

Questions explored in the caucus groups may be: 1) What is easy/difficult about being a member of this group in this society or on campus? 2) What messages were you taught about being a member of this group growing up (e.g., family, school, neighborhood, places of worship, media)? What has been the impact of that socialization on your life? Consider some of the costs and benefits, and 3) Are there any questions you would like to ask other people in this group about what it is like for them to be a member of this group? Specific readings are assigned to each group to prompt discussion, such as Penny Rosenwasser's (2013) Chapter "Taking Egypt out of the Jews," and colorism in Arab communities (Walid, 2014). Free writing may be used as well to promote student reflection. The caucuses then come back together in a large group, and explore the process, what the activity was like, and also the content and what was discussed. These groups are used twice during the semester, in week three and week six. 
The next approach is to incorporate, at the beginning of the dialogue, information and discussion of the Jewish history of oppression. Jewish history is one fraught with repeated traumas on both a micro and macro level. From the pogroms to the Dreyfus Affair to the Holocaust to housing discrimination against Jews in the United States, the Jewish people have a history that tells them they will not be safe living under non-Jewish rule (Bar-Tal, 2007). Even in the current American Jewish climate, where the majority of Jews now access white privilege and benefit from multiple other privileges, the memory of this trauma remains. Trauma is passed on from generation to generation, and thus many young Jewish Americans who have known primarily privilege have an overwhelming sense of marginalization and fear that must be addressed (Dessel et al., 2014).

Addressing historical Jewish trauma is not meant to decenter the dialogue from Palestinian trauma nor Jewish oppression of Palestinians. Rather, it is meant to do two things. One, allow Jewish students to have their traumas acknowledged, which opens their ability to move beyond a sense of victimization and reduces their resistance to acknowledging their privileges. Two, it provides both Arab and Jewish students with a place from which to understand anti-Semitism and begin to disentangle anti-Semitism from resistance to the Israeli occupation. Anti-Semitism has long been defined and represented as bias and prejudice against Jews (Dart, 2015). Anti-Zionism may be understood as opposition to the establishment of a homeland in Palestine for the Jewish people, and often these two terms have been conflated (Corrigan, 2009; Klug, 2013). Recently, for example, a Jewish student at UCLA was assumed to have a pro-Israel bias and her ability to serve on the student judicial board questioned (Kosmin, 2015). It is important that Arab students recognize the historical experiences Jewish people have with oppression and trauma, and that Jewish students understand the difference between prejudice against Jewish people, and criticism of and resistance to the Israeli government's oppressive policies and practices toward Palestinians.

Intersectionality is a theory that refers to the concept of having multiple oppressed social identities, for example being both Arab American and being a woman, and that takes into account the unique and complex experiences of these different social identities and how they might contribute to social inequality (Cole, 2009; Collins, 2000; Crenshaw, 1989). For example, Arab American women may experience oppression for being an ethnic minority, and also based on societal sexism. Intersectionality research also looks at the interaction of having a privileged and an oppressed identity (Croteau, Talbot, Lance, \& Evans, 2002; Spanierman, Bear \& Todd, 2012). So for example, some Jewish people may experience white racial privilege in the United States, but also experience religious oppression and anti-Semitism for being Jewish. This intersectional approach helps students examine the complexity of social identities, such that they may hold both privileged and oppressed identities, and that no one oppression is more or less than another, and that everyone may contribute in some way to societal structures of oppression (Adams et al., 2007; Hahn 
Tapper, 2013). An intersectional lens supports the examination of intra-group dynamics, so for example gender or race dynamics within Arab or Jewish communities (Hahn Tapper, 2013), or the idea that Arab American Christians hold more privilege than Arab American Muslims (Jaschik, 2005). In this way, the power imbalances that are important to the normalization discussion may be better understood when considering other social inequalities (Dessel, Massé, \& Walker, 2013).

\section{Facilitation}

Multipartial facilitation is a facilitation approach that has been described in varied ways by dialogue practitioners (Korza, Assaf, \& Bacon, 2012; Pruitt \& Thomas, 2007; Routenberg \& Sclafani, 2010). In contrast to neutral or impartial facilitation, which does not take any position on a particular issue, multipartial facilitation means establishing trust with and engaging all sides and participants (Pruitt \& Thomas, 2007; Korza et al., 2012), while paying special attention to the power imbalances that exist among different social identities (Ben Hagai et al., 2013; Zuniga et al., 2007). Multipartial facilitation recognizes the dominant narratives in society that promote the experiences of people who hold more dominant social positions (Wing \& Rifkin, 2001), challenges these narratives, invites in the counter narratives of people from less heard positions, and encourages all dialogue participants to critically analyze these dominant or master narratives (Takaki, 2008). Paying attention to who is speaking in the group and for how long, asking specific questions to raise awareness about social inequality, encouraging sharing of personal narratives, and suspending judgment of privileged groups while not expecting the marginalized groups to always educate or challenge are all methods of this type of facilitation (Routenberg \& Sclafani, 2010).

Co-facilitation by two different social identities also takes into account this facilitation approach, as facilitators acknowledge their own identities and how these identities affect the group process in their work to support all participants (Zúniga et al., 2007). In this way, the experiences of Palestinian or Arab students can be heard, and Israeli and Jewish narratives can be more closely examined. In order to address normalization in intergroup dialogues, it is important for facilitators to have the ability to recognize and understand normalization, and then to educate participants about normalization in dialogue. This can be achieved through educating facilitators about the concept, and providing them with the above mentioned facilitation tools.

\section{Populating the Dialogue}

Another method or approach to addressing normalization in intergroup dialogue is to intentionally engage participants in dialogue who share similar values and goals of pursuing Palestinian human rights and ending the Israeli occupation of Palestine. In this approach, dialogue is seen as a tool to resist or end oppression, therefore disrupting the binary between activism (including BDS) and dialogue (Dessel \& Ali, 2012b; Hahn Tapper, 2011; Hallward, 2011). This approach is a complicated one, 
as not all dialogue programs have the opportunity to screen participants in this way, and some do not endorse this method of engaging those who are already aligned with Palestinian or Arab advocacy or activism.

Many intergroup dialogue programs aim for equal numbers of participants from both groups and equal status in terms of socioeconomic or educational backgrounds (Maoz, 2001, Yazbak-Abu Ahmad \& Yahav, 2015). The goals of the dialogue can also affect recruitment, as Arab participants may want more attention to political issues, while Jewish participants may want to focus more on interpersonal relationship building (Rouhana \& Korper, 1996).

Alternatively, other dialogue approaches seek to engage Jewish students who are less informed or have a wider range of opinions. In these dialogues, the rationale is reaching those students who are misinformed or less informed and giving them a chance to learn more about the conflict and consequently test their misconceptions (Yazbak-Abu Ahmad \& Yahav, 2013). The four stage dialogue model intentionally engages students in a group process that is designed to create a safe space for exploration, an opportunity to learn about social identity and dialogic communication skills, engagement across conflict, and movement toward social change actions (Zuniga et al., 2007). In this way, concerns about normalization are addressed by not expecting students to commit to resistance against Israeli occupation before they have learned about Palestinian lives. Finally, intra-Jewish approaches to educating less informed Jewish students could avoid concerns about power dynamics related to normalization (http://www.jewishdialogue.org).

\section{Conclusion}

Normalization is a controversial and complex issue, and it can mean different things for Palestinians in different parts of the world. It is critical to recognize that Palestinians in Israel, West Bank, Gaza, and the diaspora have different experiences around engagement with Jewish people and with Israel (Ben-David, 2012; Dakwar, 2006; Halper, 2006). There continue to be disagreements about the Palestinian/Israeli conflict and subsequently BDS, and related, whether Arabs want to engage in dialogue with people who are not fully supportive of Palestinian equality and justice on issues related to Palestine.

Activism around the Israel/Palestinian conflict across college campuses is gaining momentum (Kurwa, 2013b, McMahon, 2014). Divestment campaigns such as BDS are raising awareness about the occupation and Palestinian human rights issues. Students need support from college administrators and faculty around this issue, and power and resources inequalities need to be recognized and addressed.

Human rights for Palestinians have become an increasingly important issue that cannot be ignored by Jewish Americans or by Israeli Jews (Ellis, 2014; Jewish Voice for Peace, 2015; Landy, 2011). Jewish Voice for Peace and the Open Hillel movement have been gaining ground and provide models for Jewish students to work in 
solidarity with Palestinians. Faculty and staff on college campuses can support all students in exploring these critical issues and can utilize IGD pedagogy to support students who experience tensions on campus related to the Israeli Palestinian conflict.

IGD and other intergroup efforts need to take the issue of normalization and power relations into account (Pettigrew, Tropp, Wagner, \& Christ, 2011; Saguy et al., 2008) and address other critiques that have been brought forth by student activists (Kurwa, 2013a, 2014; Radi, 2014). This article provides a model of IGD that relates to the topic of normalization by describing this issue, and provides examples of how students learn about normalization and tackle it in their classroom environment. Faculty and others can use this pedagogy to engage students on college campuses who are passionate about this issue, to promote their skills in conflict management, and to foster improved relationships.

\section{References}

Abu-Nimer, M. (1995). Confict resolution and dialogue in Arab-Jewish relations in Israel: A case of change and control. Paper presented at the American Sociological Association annual meeting, Toronto.

Abu-Nimer, M. (1999). Arab-Jewish conflict in Israel: Historical, social, and political background. In M. Abu-Nimer (Ed.), Dialogue, conflict resolution, and change: Arab-Jerwish encounters in Israel (pp. 29-36). Albany, NY: SUNY Press.

Abu-Nimer, M. (2004). Education for coexistence and Arab Jewish encounters in Israel: Potential and challenges. Journal of Social Issues, 60, 405-422.

Abu Sarah, A. (2011, December 26). What is normal about normalization? 972 mag. Retrieved from http://972mag.com/what-is-normal-about-normalization/31262/

Adams, M., Bell, L. A., \& Griffin, P. (Eds.), (2007). Teaching for diversity and social justice. New York, NY: Routledge.

Allport, G. W. (1954). The nature of prejudice. New York, NY: Addison-Wesley.

Anonymous, (2011, April 5). Institute for Jewish and Community Research Expresses Concern About Information Regarding the University of California. Professional Services Close - Up. Retrieved from http://search.proquest.com.proxy.lib.umich.edu/docview/860018593?pq-origsite= summon\&accountid $=14667$

Anonymous (2013, May 11). Boycotting the boycotters; Palestinians in Israel. The Economist. Retrieved from http://search.proquest.com.proxy.lib.umich.edu/docview/1350227326?pq-origsite= summon\&accountid $=14667$

Azaizeh, A. (2015, January). The road to Tel Aviv does not pass through Acca. (Electronic version). AlSafeer. Retrieved from http://palestine.assafir.com/Article.aspx?ChannelID =1\&ArticleID = 3179

Bar-Tal, D. (2007). Living with the conflict: Socio-Psychological analysis of the Jewish society in Israel. Jerusalem, Israel: Carmel Books.

Barghoti, O. (2014). The BDS star: The frontline spot. (Electronic version). The Palestinian Studies Journal 25(99). Retrieved June from http://palestine.assafir.com/Article.aspx? ArticleID=2919. 
Bekerman, Z. (2007). Rethinking intergroup encounters: Rescuing praxis from theory, activity from education, and peace/co-existence from identity and culture. Peace Education, 4, 2941.

Ben-David, A. (2012). The Palestinian diaspora on the Web: Between de-territorialization and reterritorialization. Social Science Information, 51, 459-474.

Ben Hagai, E., Hammack, P. L., Pilecki, A., \& Aresta, C. (2013). Shifting away from a monolithic narrative on conflict: Israelis, Palestinians, and Americans in conversation. Peace and Conflict: Journal of Peace Psychology. Advance online publication. doi:10.1037/a0033736.

Biton,Y. (2002). Israeli and Palestinian's understanding of "peace" as a function of their participation in peace education programs. (Unpublished doctoral dissertation). University of Haifa, Israel.

Buie, S., \& Wright, W. (2010). The difficult dialogues initiative at Clark University: A case study. New Directions for Higher Education, 152, 27-34. doi:10.1002/he.409.

Charmaz, K. (2011). Grounded theory methods in social justice research. The Sage Handbook of Qualitative Research, 4, 359-380.

Collins, P. H. (2000). Black feminist thought: Knowledge, consciousness, and the politics of emporverment. New York, NY: Routledge.

Cole, E. (2009). Intersectionality and research in psychology. American Psychologist, 64, 170-180.

Corrigan, E. (2009). Is anti-Semitism anti-Semitic? Jewish Critics Speak. Middle East Policy XVI, $146-159$.

Crenshaw, K. (1989). Demarginalizing the intersection of race and sex: A black feminist critique of antidiscrimination doctrine, feminist theory and antiracist politics. University of Chicago Legal Forum, 140, 139-168.

Croteau, J. M., Talbot, D. M., Lance, T. S., \& Evans, N. J. (2002). A qualitative study of the interplay between privilege and oppression. Journal of Multicultural Counseling and Development, $30,239-258$.

Dakwar, J. (2006). Underclass citizens: Palestinians in Israel. Journal of Palestine Studies, 35, 62-72. Retrieved May 20, 2015 from http://history.berkeley.edu/sites/default/files/Strategy.139.pdf

Dart, J. (2015). Israel and a sports boycott: Antisemitic? Anti-Zionist?. International Review for the Sociology of Sport, 1-25. doi:10.1177/1012690215583482

Dessel, A., \& Ali, N. (2012a). The Minds of Peace and intergroup dialogue: Two complementary approaches to peace. Israel Affairs (Special Issue), 18, 123-139.

Dessel, A., \& Ali, N. (2012b). Arab/Jewish intergroup dialogue courses: Building communication skills, relationships and social justice. Small Group Research, 43, 559-590.

Dessel, A., Ali, N., \& Mishkin, A. (2014). Learning about Palestinian narratives: What are the barriers for Jewish college students? Peace and Conflict: Journal of Peace Psychology, 20, 365384.

Dessel, A., Massé, J., \& Walker, L. (2013). Intergroup dialogue pedagogy: Teaching about intersectional and under-examined privilege in heterosexual, Christian, and Jewish identities. In K. Case (Ed.), Deconstructing privilege: Teaching and learning as allies in the classroom (pp. 132148). New York, NY: Routledge.

Ellis, M (2014). Rabbi Brant Rosen steps down from Jewish Reconstructionist Synagogue saying his activism on Israel/Palestine has been lightning rod for division. Mondoweiss. Retrieved from http://mondoweiss.net/2014/09/reconstruction-synagogue-israelpalestine 
Ghanem, A. \& Mustafa, M. (2011). The Palestinians in Israel: The challenge of the indigenous group politics in the 'Jewish State'. Journal of Muslim Minority Affairs 31, 177-196.

Gravois, J. (2004, November 19). A history course forces students to look at both sides of the Israeli-Palestinian conflict. The Chronicle of Higher Education, 51(13). Retrieved from http:// chronicle.com/article/A-History-Course-Forces-Stu/9447/

Gross, R., \& Williams, Z. E. (2009, March 12). Video calls recall into question. The Daily Californian. Retrieved from http://archive.dailycal.org/article/104796/video_calls_recall_into_question

Hahn Tapper, A. (2011). The war of words: Jews, Muslims, and the Israeli-Palestinian conflict on American university campuses. In R. Aslan \& A. Hahn Tapper (Eds.), Muslims and Jews in America: Commonalities, contentions, and complexities, (pp. 71-92). New York, NY: Palgrave Macmillan.

Hahn Tapper, A. J. (2013). A pedagogy of social justice education: Social identity theory, intersectionality, and empowerment. Conflict Resolution Quarterly, 30, 411-445. doi:10.1002/crq.21072.

Halabi, R. (Ed.). (2000). Israeli and Palestinian identities in dialogue: The school for peace approach. New Brunswick, NJ: Rutgers University Press.

Hallward, M. (2011). Pursuing "peace" in Israel/Palestine. Journal of Third World Studies, 28, 185-202.

Halper, H. (2006). A strategy within a non-strategy: Sumod, resistance, attrition, and advocacy. Journal of Palestine Studies, 35(3), 45-52. Retrieved April 19, 2015 from http://history.berkeley. edu/sites/default/files/Strategy.139.pdf

Hamdan, A. \& Awad, Y. (2010). The equality index of Jerwish and Arab citizens in Israel. Sikkuy, the Association for the Advancement of Civic Equality. Jerusalem-Haifa, Israel: The Kahanov Foundation.

Hanania, R. (2011, December 27). Yalla peace: The abnormality of 'normalization'. Retrieved from http://rayhanania.com/2011/12/27/yalla-peace-the-abnormality-of-normalization/

Hubbard, A. (1997). Face-to-face at arm's length: Conflict norms and extra-group relations in grassroots dialogue groups. Human Organization, 56, 265-274.

If Americans Knew (2015). Retrieved from http://www.ifamericansknew.org/stat/usaid.html

Jaschik, S. (2005, August 22). Different kinds of diversity. Inside Higher Ed. Retrieved from http:// www.insidehighered.com/news/2005/08/22/counseling

Jewish Voice for Peace. (2015). Retrieved from jewishvoiceforpeace.org

Just Associates. (2006). Making change happen: Power. Washington, DC. Retrieved from justassociates.org

Karayanni, M. M. (2009). Choice of law under occupation: How Israeli law came to serve Palestinian plaintiffs. Journal of Private International Law 5, 1-48.

Keilani, T., and Heitner, E. (2013, February 11). Nothing "Normal" about it: Dialogue, normalization and Palestine on campus (Web blog). endtheoccupation. Retrieved from http://endtheoccupation.org/downloads/nothingnormalbooklet.pdf

Khuri, M. L. (2004a). Facilitating Arab-Jewish intergroup dialogue in the college setting. Race, Ethnicity, and Education, 7, 229-250. doi:10.1080/1361332042000257056.

Khuri, M. L. (2004b). Working with emotion in educational intergroup dialogue. International Journal of Intercultural Relations, 28, 595-612. doi:10.1016/j.iiintrel.2005.01.012.

Klug, B. (2013). Interrogating 'new anti-Semitism.' Ethnic and Racial Studies 36, 468-482. 
Koren, H. (2002). The Arab citizens of the state of Israel: The Arab media perspective. Israel Affairs, 9, 212-226. doi:10.1080/714003481.

Korza, P., Assaf, A., \& Bacon, B. S. (2012). INROADS: The Intersection of Art E Civic Dialogue. Retrieved from https://www.clarku.edu/difficultdialogues/pdfs/INROADS.pdf

Kosmin, B. (2015, March 10). UCLA student is latest victim of anti-Semitism on campus. CNN. Retrieved May 21, 2015 from http://www.cnn.com/2015/03/10/opinions/kosmin-anti-semitism-campus/

Kurwa, R. (2013a, February 6). Why students in solidarity with Palestine should not join The Olive Tree Initiative. Jadaliyya. Retrieved May 19, 2015 from http://www.jadaliyya.com/pages/ index/10009/why-students-in-solidarity-with-palestine-should-n

Kurwa, R. (2013b, Jul/Aug). BDS campaigns sweeps UC campuses: Checkpoint California. Against the Current, 28(3), 7-10. Retrieved on May 4, 2015 from https://solidarity-us.org/ node/3930

Kurwa, R. (2014, January 28). Dialogue in the service of power: UC leadership's anti-divestment strategy. Jadaliyya. Retrieved May 19, 2015 from http://www.jadaliyya.com/pages/index/16222/ dialogue-in-the-service-of-power_uc-leaderships-an

Landy, D. (2011). Jewish identity and Palestinian rights: diaspora opposition to Israel. London, UK: Zed Books.

Lopez, H. M. (2003, October 3). Hundreds attend debate on Israeli-Palestinian conflict. The Daily Californian. Retrieved from http://archive.dailycal.org/article/12977/hundreds_attend_debate_on_israeli-palestinian_conf

Lopez-Humphreys, M. \& Dawson, B. A. (2014). From education to action: The immediate and long-term results of intergroup dialogue on BSW students' social justice activity. The Journal of Baccalaureate Social Work, 19, 31-43.

Maoz, I. (2000). Multiple conflicts and competing agendas: A framework for conceptualizing structural encounters between groups in conflict-The case of a coexistence project of Jews and Palestinians in Israel. Peace and Conflict: Journal of Peace Psychology, 6, 135-156.

Maoz, I. (2001). Participation, control, and dominance in communication between groups in conflict: Analysis of dialogues between Jews and Palestinians in Israel. Social Justice Research, 14, 189-208.

Maoz, I. (2011). Does contact work in protracted asymmetrical conflict? Appraising 20 years of reconciliation-aimed encounters between Israeli Jews and Palestinians. Journal of Peace Research 2011, 48, 15-125. doi: 10.1177/0022343310389506

McMahon, S. F. (2014). The boycott, divestment, sanctions campaign: Contradictions and challenges. Race \& Class 55, 65-81.

Mollov, B., \& Lavie, C. (2001). Culture, dialogue and perception change in the Israeli-Palestinian conflict. The International Journal of Conflict Management, 12, 69-87. doi:10.1108/eb022850.

National Students for Justice in Palestine (2014, October 24-26). Students for justice in Palestine: Fourth National Conference 2014. SJP National. Retrieved from http://sjpnational.org

PACBI. (2015). Palestinian campaign for the academic \& cultural boycott of Israel. PACBI. Retrieved from http://www.pacbi.org

Palestinian Central Bureau of Statistics. (2009). Press release on the Palestinians in the world (December). Palestinian Central Bureau of Statistics. Retrieved from http://www.pcbs.gov.ps/ Portals/_pcbs/PressRelease/pop_2009-E.pdf. 
Pettigrew, T. F., \& Tropp, L. R. (2006). A meta-analytic test of intergroup contact theory. Journal of Personality and Social Psychology, 90, 751-783. doi:10.1037/0022-3514.90.5.751.

Pettigrew, T. F, Tropp, L. R., Wagner, U., \& Christ, O. (2011). Recent advances in intergroup contact theory. International Journal of Intercultural Realtions, 45, 271-280.

Pruitt, B., \& Thomas, P. (2007). Democratic dialogue: A bandbook for Practitioners. New York, NY: Canadian International Development Agency (CIDA), the International Institute for Democracy and Electoral Assistance (IDEA), the Organization of American States (OAS), and the United Nations Development Programme (UNDP).

Radi, T. (2014, March 21). Slim peace's slim chances for justice. Mondoweiss. Retrieved from http://mondoweiss.net/2014/03/peaces-chances-justice

Radi, T. (2015, February 3). How students are resisting efforts to normalize Israeli apartheid. Electronic Intifada. Retrieved from http://electronicintifada.net/content/how-students-are-resistingefforts-normalize-israeli-apartheid/14218

Rahman, O. (2012, January 3). + 972 Magazine. Retrieved from http://972mag.com/co-existencevs-co-resistance-a-case-against-normalization/32076/

Rosenwasser, R. (2013). Hope into practice Jewish women choosing justice despite our fears. Retrieved from Pennyrosenwasser.com

Rouhana, N., \& Korper, S. (1996). Case analysis: Dealing with dilemmas posed by power asymmetry in intergroup conflict. Negotiation Journal, 12, 353-366.

Routenberg, R. \& Sclafani, T. (2010, Fall \& Winter). Facilitating through "perfectly logical explanations (PLEs)" and other challenging participant comments. ACPA Commission for Social Justice Educators Newsletter.

Saguy, T., Dovidio, J., \& Pratto, F. (2008). Beyond contact: Intergroup contact in the context of power relations. Personality and Social Psychology Bulletin, 34, 432-445. doi:10.1177/ 0146167207311200

Schworm, P. (2009, February 12). Hampshire College cuts ties with fund invested in Israel. The Boston Globe. Retrieved from http://www.boston.com/news/local/breaking_news/2009/02/hamphire_colleg.html

Sharoni, S. (1995). Gender and the Israeli-Palestinian conflict: The politics of women's resistance. Syracuse, NY: Syracuse University Press.

Shibley, R. (2014, March 18). Don't let the Israeli- Palestinian conflict overwhelm free speech on campus. Forbes. Retrieved from http://www.forbes.com/sites/realspin/2014/03/18/dont-let-theisraeli-palestinian-conflict-overwhelm-free- speech-on-campus/

Solomon, G. (2004). A narrative-based view of coexistence education. Journal of Social Issues, 60, 273-287.

Spanierman, L.B., Bear, J.C., \& Todd, N. R. (2012). White men's fears, White women's tears: Examining gender differences in racial affect types. Sex Roles, 67, 174-186.

Suleiman, R. (2004). Planned encounters between Jewish and Palestinian Israelis: A socialpsychological perspective. Journal of Social Issues, 60, 323-337.

Takaki, R. (2008). A different mirror: A history of multicultural America. New York, NY: Hachette.

Thawaba, S. A. (2009). Urban growth of a city under siege: Tulkarm, Palestine over the past century. Journal of Planning History, 8(1). February 27-46. doi:10.1177/1538513208327682. 
The Third Narrative. (2015, March 16). "Anti-Normalization" prevents peace, sustains the occupation, undermines academic freedom, and harms students. Retrieved from http://thirdnarrative.org/israelpalestine-articles/anti-normalization-prevents-peace-sustains-the-occupation-undermines-academicfreedom-and-harms-students/

Wagner M., Frantzman. S. J., \& Kelly, L. (2015, March 18). Hope and frustration abound with historic election results in Arab community". Jerusalem Post. Retrieved on May 18, 2015 from http://www.jpost.com/Israel-Elections/Hope-and-frustration-abound-with-historic-electionresults-in-Arab-community-394295

Walid, D. (2014, March 3). Responses to my calling out the term 'Abeed'. The Arab American Nerws. Retrieved from http://theamericanmuslim.org/tam.php/features/articles/responses-tomy-calling-out-the-term-abeed

Walid, S. (2005). The anti-normalization discourse in the context of Israeli-Palestinian peacebuilding. Palestine - Israel Journal of Politics, Economics, and Culture 12.1. 100-109.

Wing, L. \& Rifkin, J. (2001). Racial identity development and the mediation of conflicts. In C. L. Wijeyesinghe \& B. W. Jackson III (Eds.). New perspectives on racial identity development: $A$ theoretical and practical anthology (pp. 182-208). New York, NY: New York University Press.

Yazbak-Abu Ahmad, M. \& Yahav, A. (2013). Humanizing the other. Teacher Education Advancement Network (TEAN) 6(1), 41-54.

Yazbak-Abu Ahmad, M. \& Yahav, A. (2015). Dealing with diversity in the classroom, In K. Arar, A. Kinan, \& M. Mustafa (Eds.), Identity, narrative and multiculturalism in Arab education in Israel (pp. 237-264). Haifa, Israel: Pardes.

Zúñiga, X., Nagda, B. R., Chesler, M., \& Cytron-Walker, A (2007). Intergroup dialogue in higher education: Definition, origins, and practices (ASHE-ERIC Report Series, vol. 32, No. 4, pp. 1-128). Hoboken, NJ: Jossey-Bass. doi:10.1002/aehe.3204. 